\title{
Effect of gibberellic acid at different phenological stages on the quality of plum
}

\author{
Waqas Khan ${ }^{1 *}$, Saleem Khan ${ }^{2}$, Mehnaz Ghaffar ${ }^{2}$, Asad Ali Khan ${ }^{1}$, \\ Muhammad Ilyas ${ }^{1}$ and Babar Ali $^{1}$
}

1. Department of Horticulture, The University of Agriculture Peshawar, KP-Pakistan

2. Agricultural Research Station, Baffa, Mansehra, KP-Pakistan

*Corresponding author's email: waqas.agri@yahoo.com

Citation

Waqas Khan, Saleem Khan, Mehnaz Ghaffar, Asad Ali Khan, Muhammad Ilyas and Babar Ali. Effect of gibberellic acid at different phenological stages on the quality of plum. Pure and Applied Biology. Vol. 7, Issue 4, pp12441251. http://dx.doi.org/10.19045/bspab.2018.700144

\begin{tabular}{llll}
\hline \hline Received: 27/05/2018 & Revised: 16/08/2018 & Accepted: 23/08/2018 & Online First: 30/08/2018 \\
\hline \hline
\end{tabular}

\section{Abstract}

The experiment was conducted at Agricultural Research Institute Tarnab, Peshawar, Pakistan during the year of 2017. Different concentrations of Gibberellic acid $\left(\mathrm{GA}_{3}\right)$ i.e., 0,20 and $30 \mathrm{ppm}$ were sprayed at two different phenological stages i.e. at full bloom and after fruit set $(80 \%$ petal fall) and the results were compared with control treatment. The experiment was laid out in two factors Randomized Complete Block Design with Split Plot arrangement having three replications. The results revealed that treatment of $\mathrm{GA}_{3}$ concentrations at different phenological stages had significant effect on the parameters having high total soluble solids (8.85), low fruit $\mathrm{pH}(4.49)$, maximum sugars $(9.12 \%)$, low acidity $(0.18 \%)$, high sugar: acid ratio (52.01) and high vitamin $\mathrm{C}$ content $(5.54 \mathrm{mg} / 100 \mathrm{~g})$ with the application of $\mathrm{GA}_{3}$ after fruit set while, low total soluble solids (8.03), high fruit $\mathrm{pH}(4.86)$, minimum sugars $(8.98 \%)$, high acidity $(0.21 \%)$, low sugar: acid ratio (43.43) and high vitamin $\mathrm{C}$ content $(5.34 \mathrm{mg} / 100 \mathrm{~g})$ were recorded with $\mathrm{GA}_{3}$ application at full bloom. Gibberellic acid at $30 \mathrm{ppm}$, resulted in highest total soluble solids (9.44), low fruit $\mathrm{pH}$ (4.03), maximum sugars $(9.16 \%)$, low acidity $(0.17 \%)$, high sugar: acid ratio (54.40) and high vitamin $\mathrm{C}(5.63$ $\mathrm{mg} / 100 \mathrm{~g}$ ) while, the lowest total soluble solids (7.23), high fruit $\mathrm{pH}$ (5.51), minimum sugars (8.88\%), high acidity (0.22 \%), low sugar: acid ratio (40.41) and low vitamin C contents $(5.22 \mathrm{mg} / 100 \mathrm{~g}$ ) were recorded in untreated control trees. From the current investigation it can be concluded that the treatment of $\mathrm{GA}_{3}$ at $30 \mathrm{ppm}$ after fruit set found better in most of quality attributes of plum as compared to control.

Keywords: Gibberellic acid; Phenological stages; Plum; Quality

\section{Introduction}

Plum (Prunus domestica L.) is a stone fruit of the family Rosaceae, locally known as Alocha and Alobukhara. The fruit develops with seed having a hard shell or stone. The inner part of the ovary wall develops into seed and the outer part into soft flesh [1]. Different plum species are originated in different parts of the world such as Prunus domestica (European plum) in Europe, Prunus insititia (Damson plum) in Western Asia, Prunus salicina (Japanese plum) in
China, Prunus cerasifera (cherry plum) in Western and Central Asia and Prunus americana (American plum) in North America [2, 3]. There are fifteen cultivated species of plum in which Prunus domestica (European Plum) and Prunus salicina (Japanese plum) are commonly grown in Pakistan [4, 5]. Plum is a rich source of vitamin $\mathrm{A}$, vitamin $\mathrm{C}$, iron and fibers. It is consumed in fresh, dry, canned, and also preserved into jams and jellies $[6,7]$. 
In Pakistan, total area under plum cultivation was 7019 hectares (ha) which included 26 ha in Punjab, 2981 ha in Khyber Pakhtunkhwa and 4012 ha in Baluchistan. Total production was 54304 tonnes which represented production of 172, 26269 and 27863 tonnes in Punjab, KP and Baluchistan respectively [8].

The plant growth regulators required in small quantities and at low concentrations to carry message from one part to another part of the plant for performing certain actions. Similarly, they are synthesized in one place and go to the other place to perform different functions. Moreover, plant growth regulators improve productivity by changing physiological and biochemical characteristics of a crop through rapid mobility inside plant $[9,10]$.

Gibberellic acid has three important actions which include the ability of an organ to be used as a sink for the nutrients, the increase in synthesis of IAA in plant tissues and acceleration of hydrolytic enzymes synthesis in Aleurone cells [11, 12]. Gibberellic acid has great effect on plant physiological systems including fruit setting, leaf expansion, germination, breaking dormancy, increasing fruit size, improving fruit quality and many other aspects of plant growth and crop production [13]. Gibberellic acid at 30 and 40 ppm was considered effective treatment when applied after berry set which resulted in improving quality of sharad seedless grapes $[14,15]$.

In view of these prospective, an attempt has been made to find out the suitable treatment which could improve the quality of plum. Therefore, the present research study "Effect of Gibberellic acid at different phenological stages on the quality of plum" was designed and conducted at Agricultural Research

Factor A

Main Plot

Phenological stages
Institute Tarnab, Peshawar during the year, 2017 with the following objectives:

\section{Objectives}

To find the optimum concentration of $\mathrm{GA}_{3}$ for fruit quality of plum

To find the proper phenological stage for spray for the increase in quality attributes in plum

To find the interactive effect of $\mathrm{GA}_{3}$ and phenological stage on quality of plum

\section{Materials and methods}

The present experiment was carried out at Agricultural Research Institute Tarnab, Peshawar, Khyber Pakhtunkhwa, Pakistan during 2017. The experiment was laid out in two factors Randomized Complete Block Design (RCBD) with Split Plot arrangement having three replications. Eighteen trees (10 years old; receiving same cultural practices and are in healthy condition and vigor) of plum cv. Red Beaut (Prunus salicina, L.) budded on Peshawar local peach rootstock were selected. Different concentrations of $\mathrm{GA}_{3}$ i.e. 0,20 and $30 \mathrm{ppm}$ were sprayed at different phenological stages included phase at full bloom and after fruit set $(\approx 80 \%$ petal fall) and their results were compared with control treatment.

\section{Treatments}

Aqueous solutions of 20 and 30ppm were prepared according to the standard formula (2.5 $\mathrm{g}_{\text {of }} \mathrm{GA}_{3}$ dissolved in 100 liter of water $=10$ ppm) given by product ProGibb ${ }^{\circledR}$. Chemical weight for $10 \mathrm{ppm}$ was find out for $10 \mathrm{~L}$ distilled water treatment ${ }^{-1}$ as (No. of grams dissolved in $10 \mathrm{~L}=\frac{2.5 \mathrm{~g} \times 10 \mathrm{~L}}{100}$ and then the chemical weight for $10 \mathrm{ppm}$ multiplied by 2 and 3 for making 20ppm and $30 \mathrm{ppm}$ solutions respectively [16]. These solutions were applied at two different phenological stages that is, at full bloom and after fruit set.

\section{Factor B}

$\underline{\text { Sub Plot }}$

$\mathrm{GA}_{3}$ concentrations 


\begin{tabular}{|c|c|}
\hline $\mathrm{PS}_{1}=$ At full bloom & $\mathrm{G}_{1}=0 \mathrm{ppm}$ (Control) \\
\hline $\mathrm{PS}_{2}=$ After fruit set & $\mathrm{G}_{2}=20 \mathrm{ppm}$ \\
\hline & $\mathrm{G}_{3}=30 \mathrm{ppm}$ \\
\hline
\end{tabular}

\section{Study parameters}

The following bio-chemical parameters were studied.

\section{Total Soluble Solids (TSS ${ }^{\circ}$ Brix)}

The total soluble solids of 10 fruits randomly selected, were measured by using hand Refractometer, according to method described in [17]. The means were calculated.

\section{Fruit pH}

Fruit $\mathrm{pH}$ was described with the help of electronic $\mathrm{pH}$ meter before keeping the electrode of $\mathrm{pH}$ meter in plum juice, the $\mathrm{pH}$ meter was standardized by $\mathrm{pH}$ buffer solution and $\mathrm{pH}$ of the plum was determined by taking fruit sample from every treatment in each replication and their average was taken.

\section{Total sugars (\%)}

Sugars content of 10 randomly selected fruits were determined by analyzing the sample in Food Technology lab, according to method described in [17]. The average was counted.

\section{Acidity (\%)}

Acidity of 10 randomly selected fruits were determined by analyzing the sample in Food Technology lab, according to method described in [17]. The average was counted.

\section{Sugar acid ratio}

The ratio of sugar and acid was determined by sugar contents divided by acid contents of the fruits.

\section{Vitamin C (mg/100gm)}

Vitamin $\mathrm{C}$ content of 10 randomly selected fruits were determined by analyzing their sample in Food Technology lab, according to method described in [17]. The average was counted.

\section{Statistical analysis}

All data were tested by the analysis of variance (ANOVA) for treatment effects on analyzed parameters. Means of the treatments were separated and compared by using the Least Significant Differences at 5\% level of significance according to [18]. The statistical analysis was performed by using Statistix 8.1 computer statistical Software.

\section{Results and discussion}

The results obtained of different parameters are discussed as below.

\section{Total soluble solids (TSS ${ }^{\circ}$ Brix)}

Mean (Table 1) shows that $\mathrm{GA}_{3}$ concentrations, phenological stages and interaction between them significantly affected the total soluble solids. Maximum TSS (8.85) was recorded with $\mathrm{GA}_{3}$ application after fruit set, which was declined to (8.03) with $\mathrm{GA}_{3}$ at full bloom. The mean data for $\mathrm{GA}_{3}$ concentrations revealed that the maximum TSS (9.44) was observed with 30 ppm $\mathrm{GA}_{3}$, followed by (8.65) with $20 \mathrm{ppm}$ $\mathrm{GA}_{3}$, while minimum TSS (7.23) was observed in control.

The increased in total soluble solids occurred during fruit ripening might be due to the synthesis of sucrose-phosphate, a key enzyme responsible for sucrose biosynthesis [19]. The results are similar with Ingle [20] who revealed that Total Soluble Solids and total yield are significantly increased with the foliar application of $\mathrm{GA}_{3}$ at $25 \mathrm{ppm}$ compared with control in 'Nagpur' mandarin and yield Rokaya [21] found that TSS are significantly affected by $\mathrm{GA}_{3}$ application as compared to control in mandarin. Similar evidence were observed by Saleem [22] that application of $\mathrm{GA}_{3}$ has improved Total soluble solids in 'Blood Red' sweet orange and Wahdan [23] who observed that total soluble solids was significantly increased in fruits harvested from trees sprayed with $40 \mathrm{ppm} \mathrm{GA}_{3}$ at one month after full bloom in mango as compared to control and other treatments. 
Table 1. Mean data for Total Soluble Solids ( ${ }^{\circ}$ Brix) as affected by Gibberellic acid concentrations and Phenological stages

\begin{tabular}{|c|c|c|c|c|}
\hline \multirow{2}{*}{ Phenological stages } & \multicolumn{2}{|c|}{ Gibberellic Acid Concentrations (ppm) } & Mean \\
\cline { 2 - 5 } & Control & $\mathbf{2 0}$ & $\mathbf{3 0}$ & $\mathbf{8 . 0 3 b}$ \\
\hline Full Bloom & 7.24 & 8.15 & 8.69 & $\mathbf{8 . 8 5 a}$ \\
\hline After Fruit Set & 7.22 & 9.14 & 10.19 & \\
\hline Mean & $\mathbf{7 . 2 3 c}$ & $\mathbf{8 . 6 5 b}$ & $\mathbf{9 . 4 4 a}$ & \\
\hline
\end{tabular}

\section{Fruit pH}

Mean (Table 2) shows that effect of $\mathrm{GA}_{3}$ concentrations, phenological stages and interaction between them was found significant for fruit $\mathrm{pH}$. Maximum fruit $\mathrm{pH}$ (4.86) was recorded with $\mathrm{GA}_{3}$ application at full bloom, which was declined to (4.49) with $\mathrm{GA}_{3}$ application after fruit set. The mean data for $\mathrm{GA}_{3}$ concentrations revealed that the maximum fruit $\mathrm{pH}$ (5.51) was observed in control, followed by (4.49) with $20 \mathrm{ppm} \mathrm{GA}_{3}$, while minimum fruit $\mathrm{pH}$ (4.03) was observed with $30 \mathrm{ppm} \mathrm{GA}_{3}$ application.

The fruit $\mathrm{pH}$ decreased, as well as the fruit get matured, this might be due to the conversion of acid to sugars during ripening. According to Davarynejad [24] $\mathrm{pH}$ was significantly enhanced during storage, while the $\mathrm{GA}_{3}$ application retained the $\mathrm{pH}$ of the fruit might be due to induction of tinny cover on the fruit surface which inhibit the process of degradation. During respiration the fruit juice $\mathrm{pH}$ enhanced due to the alteration of acid to sugars [25]. Results are in harmony with Bhattarai and Gautam [26] discovered that the acids inside the fruit itself utilize by the fruit which leading to enhance the $\mathrm{pH}$ of the fruit.

Table 2. Mean data for fruit $\mathrm{pH}$ as affected by Gibberellic acid concentrations and Phenological stages

\begin{tabular}{|c|c|c|c|c|}
\hline \multirow{2}{*}{ Phenological stages } & \multicolumn{2}{|c|}{ Gibberellic Acid Concentrations (ppm) } & Mean \\
\cline { 2 - 5 } & Control & $\mathbf{2 0}$ & $\mathbf{3 0}$ & $\mathbf{4 . 8 6 a}$ \\
\hline Full Bloom & 5.49 & 4.64 & 4.44 & $\mathbf{4 . 4 9 b}$ \\
\hline After Fruit Set & 5.52 & 4.34 & 3.61 & \\
\hline Mean & $\mathbf{5 . 5 1 a}$ & $\mathbf{4 . 4 9 b}$ & $\mathbf{4 . 0 3 c}$ & \\
\hline
\end{tabular}

\section{Sugars $(\%)$}

Mean (Table 3) shows that effect of $\mathrm{GA}_{3}$ concentration and phenological stages was found significant for percent sugars while interaction between them was found nonsignificant. Maximum sugars $(9.12 \%)$ was recorded with $\mathrm{GA}_{3}$ application after fruit set, which was declined to $(8.98 \%)$ with $\mathrm{GA}_{3}$ at full bloom. The mean data for $\mathrm{GA}_{3}$ concentrations revealed that the maximum sugars $(9.16 \%)$ was observed with $30 \mathrm{ppm}$ $\mathrm{GA}_{3}$, followed by $(9.10 \%)$ with $20 \mathrm{ppm} \mathrm{GA}$, while minimum sugars $(8.88 \%)$ was observed in control.

Sugars are the primary source of energy and is an important part of human diet [27] and includes in fruit parameters for quality measurement. The main sugars found in fresh plums are glucose, fructose and sucrose, although sorbitol, a sugar alcohol, are also present [28]. The results are in uniformity with the Moneruzzaman [29] and Moneruzzaman [30] they found that application of $\mathrm{GA}_{3}$ increased total sugar (\%) in the wax apple fruits compared with the control treatment. According to Saleem [22] application of $\mathrm{GA}_{3}$ in 'Blood Red' sweet orange has improved reducing sugar, nonreducing sugar and total sugar. Similarly, Sattar [31] applied gibberellic acid on Hollywood plum and observed a significant increase in reducing, non- reducing and total sugars contents. 
Table 3. Mean data for sugars (\%) as affected by Gibberellic acid concentrations and Phenological stages

\begin{tabular}{|c|c|c|c|c|}
\hline \multirow{2}{*}{ Phenological stages } & \multicolumn{3}{|c|}{ Gibberellic Acid Concentrations (ppm) } & Mean \\
\cline { 2 - 5 } & Control & $\mathbf{2 0}$ & $\mathbf{3 0}$ & $\mathbf{8 . 9 8 b}$ \\
\hline Full Bloom & 8.81 & 9.04 & 9.09 & $\mathbf{9 . 1 2 a}$ \\
\hline After Fruit Set & 8.94 & 9.17 & 9.24 & \\
\hline Mean & $\mathbf{8 . 8 8 c}$ & $\mathbf{9 . 1 0 b}$ & $\mathbf{9 . 1 6 a}$ & \\
\hline
\end{tabular}

Acidity (\%)

Mean (Table 4) shows that different Gibberellic acid concentrations, phenological stages and interaction between them affected the acidity significantly. Highest acidity $(0.21 \%)$ was measured from the trees sprayed with Gibberellic acid, at full bloom while the lowest acidity $(0.18 \%)$ was recorded at spray practiced after fruit set. Data regarding $\mathrm{GA}_{3}$ concentrations shows that fruits of maximum acidity $(0.22 \%)$ were recorded in untreated control trees pursued by acidity $(0.19 \%)$ at 20 ppm Gibberellic acid concentration while, trees treated with 30 ppm $\mathrm{GA}_{3}$ produced the fruits of minimum acidity $(0.17 \%)$.

The main acid present in plum is malic acid and its level decreases during ripening [32]. The results shows that gibberellic acid application had an extreme reducing effect on the acidity. The results are in line with $\mathrm{Li}$ and Sun [33] who revealed that $\mathrm{GA}_{3}$ treatments decreased acidity percentage in pineapple compared with control treatment, Mastuane [34] who observed that the percent acidity decreased in strawberry with the increasing concentrations of Gibberellic acid while, Tuan and Chung-Ruey [10] who observed that $\mathrm{GA}_{3}$ applications at $30 \mathrm{ppm}$ greatly decreased the acidity as compared to control treatment. Due to normal respiration and conversion to other metabolities the loss in acidity was observed [35]. Plant Growth Regulators convert the organic acids to sugar during fruit ripening and thus the reduction in titratable acidity occur Tuan and ChungRuey [10].

Table 4. Mean data for acidity (\%) as affected by Gibberellic acid concentrations and Phenological stages

\begin{tabular}{|c|c|c|c|c|}
\hline \multirow{2}{*}{ Phenological stages } & \multicolumn{3}{|c|}{ Gibberellic Acid Concentrations (ppm) } & Mean \\
\cline { 2 - 5 } & Control & $\mathbf{2 0}$ & $\mathbf{3 0}$ & $\mathbf{0 . 2 1 a}$ \\
\hline Full Bloom & 0.22 & 0.21 & 0.19 & $\mathbf{0 . 1 8 b}$ \\
\hline After Fruit Set & 0.22 & 0.17 & 0.15 & \\
\hline Mean & $\mathbf{0 . 2 2 a}$ & $\mathbf{0 . 1 9 b}$ & $\mathbf{0 . 1 7}$ & $\mathbf{c}$ \\
\hline
\end{tabular}

\section{Sugar:Acid ratio}

Mean (Table 5) revealed that different phenological stages and Gibberellic acid concentrations and their interaction affected the sugar: acid ratio significantly. Highest sugar: acid ratio $(52.01 \%)$ was measured from the trees sprayed with Gibberellic acid after fruit set, while the lowest sugar: acid ratio $(43.43 \%)$ was recorded at spray practiced at full bloom. Data regarding $\mathrm{GA}_{3}$ concentrations shows that fruits of maximum sugar: acid ratio $(54.40 \%)$ were recorded in trees treated with $30 \mathrm{ppm} \mathrm{GA}_{3}$, followed by
(48.34\%) with Gibberellic acid at 20 ppm concentration, while the minimum sugar: acid ratio $(40.41 \%)$ were noted in untreated control treatment.

The results are in line with the Mohsen [36] who reported that $\mathrm{GA}_{3}$ at $30 \mathrm{mg} / \mathrm{L}$ recorded the higher most percentages of sugar: acid ratio in grapes, Wahdan [23] who reported that sugar: acid ratio was significantly decreased in fruits harvested from trees sprayed with $\mathrm{GA}_{3}$ at full bloom in mango, and Moneruzzaman [30] observed significant changes in the sugar acid ratio due to 
different Gibberellic acid concentrations in wax apple fruits as compared to control treatments. Similarly, Sattar [31] observed a significant enhancement in sugar: acid ratio that was obtained by spraying Gibberellic acid in Hollywood plum. According to Li and Sun [33] the ratio of soluble sugar and titratable acidity was affected significantly

Table 5. Mean data for sugar: acid ratio as affected by Gibberellic acid concentrations and Phenological stages

\begin{tabular}{|c|c|c|c|c|}
\hline \multirow{2}{*}{$\begin{array}{c}\text { Phenological } \\
\text { stages }\end{array}$} & \multicolumn{3}{|c|}{ Gibberellic Acid Concentrations (ppm) } & Mean \\
\cline { 2 - 5 } & Control & $\mathbf{2 0}$ & $\mathbf{3 0}$ & \\
\hline Full Bloom & 39.48 & 43.76 & 47.04 & $\mathbf{4 3 . 4 3 b}$ \\
\hline After Fruit Set & 41.34 & 52.92 & 61.76 & $\mathbf{5 2 . 0 1 a}$ \\
\hline Mean & $\mathbf{4 0 . 4 1 c}$ & $\mathbf{4 8 . 3 4 b}$ & $\mathbf{5 4 . 4 0 a}$ & \\
\hline
\end{tabular}

\section{Vitamin C (mg/100gm)}

Mean (Table 6) revealed that different Gibberellic acid concentrations and phenological stages affected the Vitamin C significantly while their interaction was nonsignificant. Highest Vitamin C (5.54 $\mathrm{mg} / 100 \mathrm{~g}$ ) was measured from the trees sprayed with Gibberellic acid, after fruit set while the lowest Vitamin C $(5.34 \mathrm{mg} / 100 \mathrm{~g})$ was recorded at $\mathrm{GA}_{3}$ spray practiced at full bloom. In case of $\mathrm{GA}_{3}$ concentrations the fruits of maximum Vitamin C (5.63 $\mathrm{mg} / 100 \mathrm{~g}$ ) were observed in trees sprayed with Gibberellic acid concentration at 30 ppm followed by $(5.48 \mathrm{mg} / 100 \mathrm{~g})$ at $20 \mathrm{ppm}$ concentration while, in control treatment fruits of minimum Vitamin C $(5.22 \mathrm{mg} / 100 \mathrm{~g})$ were produced.

Vitamin $\mathrm{C}$ is an important part of human diet with the application of Gibberellic acid in pineapple. According to Rokaya [21] Gibberellic acid application significantly increased the Sugar/acid ratio compared to control treatment. When the sugars content increased and juice acidity decreased, the sugar/acid ratio will be increased during holding of fruit on the tree.

Table 6. Mean data for vitamin C (mg/100gm) as affected by Gibberellic acid concentrations and Phenological stages

\begin{tabular}{|c|c|c|c|c|}
\hline \multirow{2}{*}{$\begin{array}{c}\text { Phenological } \\
\text { stages }\end{array}$} & \multicolumn{2}{|c|}{ Gibberellic Acid Concentrations (ppm) } & Mean \\
\cline { 2 - 5 } & Control & $\mathbf{2 0}$ & $\mathbf{3 0}$ & \\
\hline Full Bloom & 5.16 & 5.37 & 5.49 & $\mathbf{5 . 3 4 b}$ \\
\hline After Fruit Set & 5.27 & 5.58 & 5.76 & $\mathbf{5 . 5 4 a}$ \\
\hline Mean & $\mathbf{5 . 2 2 c}$ & $\mathbf{5 . 4 8 b}$ & $\mathbf{5 . 6 3 a}$ & \\
\hline
\end{tabular}

\section{Conclusion}

Majority of parameters are positively affected by phenological stages and had significant variation which helps to save the human from many serious diseases as it is a powerful antioxidant [27]. Vitamin $\mathrm{C}$ was significantly influence by the $\mathrm{GA}_{3}$ concentrations and phenological stages as compared to control. According to Ingle [20] vitamin $C$ increases in 'Nagpur' mandarin with the foliar application of $\mathrm{GA}_{3}$ at $25 \mathrm{ppm}$ compared to control treatment. The results are similar to Saleem [22] who observed that application of $\mathrm{GA}_{3}$ in 'Blood Red' sweet orange has improved Vitamin $\mathrm{C}$ contents, and Wahdan [23] who observed that $\mathrm{GA}_{3}$ at 40 ppm after full bloom significantly increased vitamin $\mathrm{C}$ contents in mango fruits. Moneruzzaman [30] also reported that Vitamin C contents was significantly increased by $\mathrm{GA}_{3}$ application as compared to control in wax apple. 
sugars, low acidity and high vitamin $\mathrm{C}$ contents. All bio-chemical parameters of plum studied were improved by the application of $30 \mathrm{ppm} \mathrm{GA}_{3}$ than control treatments including maximum total soluble solids, sugars, low acidity, sugar: acid ratio and high vitamin $\mathrm{C}$ contents. Gibberellic acid application at $30 \mathrm{ppm}$ concentration, after fruit set was found better in most of bio-chemical parameters of plum as compared to control. Therefore, Gibberellic acid at $30 \mathrm{ppm}$ concentrations, after fruit set is recommended for the best quality production of plum under agroclimatic conditions of Peshawar valley. Further research should be conducted beyond $30 \mathrm{ppm}$ to study the effect of foliar application of $\mathrm{GA}_{3}$ on quality attributes of plum.

\section{Authors' contributions}

Conceived and designed the experiments: W Khan, Performed the experiments: W Khan, Analyzed the data: S Khan \& M Ghaffar, Contributed materials/ analysis/ tools: W Khan, Wrote the paper: W Khan, S Khan \& M Ghaffar.

\section{References}

1. Rahman N, Nabi G, Khan J \& Shafqatullah N (2000). Vegetative growth performance of different plum rootstocks. Pak J Biol Sci 3: 1630-1631.

2. Watkins R (1976). Cherry, plum, peach, apricot and almond. Simmonds N. W. (Ed.). Evolution of crop plants pp 242-247.

3. Nisar H, Ahmad M, Hussain S \& Anjum MA (2015). Biodiversity in morphophysiological characteristics of indigenous plum germplasm from Azad Jammu and Kashmir, Pakistan. Zemdirbyste Agric 102(4): 423-430.

4. Malik MN (2006). Horticulture. Fruit crops. Plums. National book foundation; Islamabad. pp 474-76.

5. Bilal W, Sajid M, Rehman KU, Ahmad N, Awan AA, Hussain B, Bacha Z, Rehman FU, Naeem A, Ali QS \& Bibi F (2015). Physical and chemical attributes of various cultivars of Plum fruit. Pure and Appl Biol 4(3): 353-361.

6. Gunnes M (2003). Some local plum varieties grown in Tokat province. Pak J Appl Sci 3(5): 291-295.

7. Shahzad M, Tahir A, Jehan N \& Luqman M (2015). Impact of different packaging technologies on post-harvest losses of stone fruits in swat Pakistan. Pak $J$ Agric Res 28(1): 53-63.

8. MNFSR (2014-15). Plum. Ministry of National Food Security and Research, Economic Wing, Islamabd, Pakistan. Table 1-5, pp 1-10.

9. Kassem HA, El-Kobbia AM, Marzouk HA \& El- Sebaiey MM (2010). Effect of foliar sprays on fruit retention, quality and yield of Costata persimmon trees. Emirates $J$ Food Agric 22(4): 259-274.

10. Tuan NM \& Chung-Ruey Y (2013). Effect of Gibberellic acid and 2, 4dichlorophenoxyacetic acid on fruit development and fruit quality of wax apple. World Academy of Sci, Engin and Technol 77: 342.

11. Addicott FT \& Addicott AB (1982). Abscission UN. GA. Press, Lts., London, England. pp 30-135.

12. Hassan HSA, Sarrwy SMA \& Mostafa EAM (2010). Effect of foliar spraying with liquid organic fertilizer, some micronutrients, and gibberellins on leaf mineral content, fruit set, yield, and fruit quality of "Hollywood" plum trees. Agric and Biol $J$ of North America 1(4): 638-643.

13. Rahman MS, Haque MA \& Mostofa MG (2015). Effect of $\mathrm{GA}_{3}$ on Biochemical Attributes and Yield of Summer Tomato. $J$ of Bioscience and Agric Res 3(2): 73-78.

14. Ramtake SD, Somkuwar RG \& Adsule PG (2011). Use of Bioregulators to improve the quality of Shrad seedlees grapes. ISHS Acta Horticul 785: 28.

15. Fathi MA, Azza I, Mohamed \& Abd El-Bary A (2011). Effect of Sitofex (CPPU) and $\mathrm{GA}_{3}$ Spray on fruit set, fruit quality, yield and monetary value of "Costata" Persimmon. Nature and Sci 9(8): 40-49.

16. Rizwan U, Sajid M, Ahmad H, Luqman M, Razaq M, Nabi G, Fahad S \& Rab A (2014). Association of Gibberellic Acid $\left(\mathrm{GA}_{3}\right)$ with Fruit Set and Fruit Drop of Sweet Orange. Jof Biol Agric and Healthcare 4(2): 54-59.

17. AOAC (2012). Official methods of analysis. Association of Official Analytical Chemists. $19^{\text {th }}$ ed. Gaithersburg, Maryland USA 2: 20877-2417. 
18. Steel, RG \& Torrie JH (1980). Principles and Procedures of Statistics, Second Edition, New York: McGraw-Hill. pp 172-177.

19. Hubbard NL, Pharr DM \& Huber SC (1991). Plant Physiol (82): 191-196.

20. Ingle HV, Rathod NG \& Patil DR (2001). Effect of growth regulators and mulching on yield and quality of Nagpur mandarin. Annals J Plant Phys 15(1): 85-88.

21. Rokaya PR, Baral DR, Gautam DM, Shrestha AK \& Paudyal KP (2016). Effect of Pre-Harvest Application of Gibberellic Acid on Fruit Quality and Shelf Life of Mandarin (Citrus reticulata Blanco). American J of Plant Sci 7: 1033-1039.

22. Saleem BA, Malik AU, Pervez MA \& Khan AS (2008). Growth regulators application affects vegetative and reproductive behavior of 'Blood Red' Sweet orange. Pak J Bot 40(5): 2115-2125.

23. Wahdan MT, Habib SE, Bassal MA \& Qaoud EM (2011). Effect of some chemicals on growth, fruiting, yield and fruit quality of "Succary Abiad" mango cv. $J$ of American Sci 7(2): 651-658.

24. Davarynejad G, Zarei M, Ardakani E \& Nasrabadi ME (2013). Influence of Putrescence Application on Storability, Post-harvest Quality and Antioxidant Activity of Two Iranian Apricot (Prunus armeniaca L.) Cultivars, Notulae. Sci Bio 5(2): 212-219.

25. Ball JA (1997). Evaluation of two lipid based edible coating for their ability to preserve post-harvest physiology of tomato. J Nepal Agric Res (7): 37-41.

26. Bhattarai DR \& Gautam DM (2006). Effect of harvesting method and calcium on harvest quality of green bell peppers. Master Diss., Faculty of the Virginia.

27. Nawaz MA, Ahmad W, Ahmad S \& Khan MM (2008). Role of growth regulators on pre-harvest fruit drop, yield and quality in Kinnow mandarin. Pak J Bot 40(5): 19711981.

28. Meredith FI, Senter SD, Forbus WR, Robertson JA \& Okie WR (1992). Postharvest quality and sensory attributes of
ByronGold and Rubysweet plums. J of Food Quality 15: 199-209.

29. Moneruzzaman MK, Hossain S, Normaniza O \& Boyce AN (2011). Growth, yield and quality responses to Gibberellic acid $\left(\mathrm{GA}_{3}\right)$ of Wax apple Syzygiumsamarangensevar. Jambu air madu fruits grown under field conditions. African J Bio 10(56): 1191111918.

30. Moneruzzaman MK, Boyce AN, Osman N \& Hossain S (2012). Physiochemical and Phytochemical Properties of Wax Apple (Syzygium samarangense [Blume] Merrill \& L. M. Perry var. Jambu Madu) as Affected by Growth Regulator Application. The Sci World J 1: 1-13.

31. Sattar A, Marzouk MH \& Al-Sabrout M (2013). Enhancement of Hollywood plum setting, retention and fruit quality. $J$ of Appl Sci Res 9(6): 4125-4131.

32. Manganaris GA, Vicente AR \& Crisosto $\mathrm{CH}$ (2008). Effect of pre-harvest and postharvest conditions and treatments on plum fruit quality Perspectives in Agriculture, Veterinary Science, Nutrition and Natural Resources 3: 009.

33. Li YH \& Sun GM (2010). Effect of gibberellic acid and N-(2-chloro-4-pyridyl)$\mathrm{N}$-phenylurea treatments on fruit quality of pineapple. Newsletter of the pineapple Working Group, International Society Horticultural Science, Hawaii 17: 18.

34. Mastuane C, Oseni TO \& Masariramb MT (2016). Effects of gibberellic acid $\left(\mathrm{GA}_{3}\right)$ on the growth, fruit yield and quality of strawberry (Fragaria ananassa) in a subtropical environment. UNISWA $J$ of Agric 19: 44-60.

35. EI-Otmani M \& Coggins JRCW (1991). Growth Regulator Effect on Retention of Quality of Stored Citrus Fruits. Scientia Horticul 45: 261-272.

36. Mohsen FS (2015). Minimizing Shot Berries Level and Improving Quality of Superior Seedless Table Grapes Using Boron and $\mathrm{GA}^{3}$. Int J Curr Res Biosci Plant Biol 2(6): 107-114. 